\title{
A Novel Class of Isoxazole Based Gelators For the Separation of Bisphenol A from Water and Clean-up of Oil Spills
}

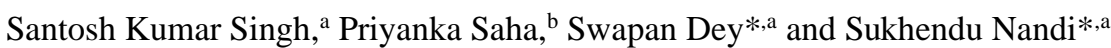

${ }^{a}$ Department of Chemistry, Indian Institute of Technology (Indian School of Mines) Dhanbad, Dhanbad 826004 , India

${ }^{\mathrm{b}}$ Environment Research Group, Research \& Development, Tata Steel Limited, Jamshedpur 831001, India.

* Author to whom correspondence should be addressed: swapan@iitism.ac.in or sukhendu@iitism.ac.in

\begin{tabular}{|l|l|l|l|}
\hline Solvent & Compound Ga & Compound Gb & Compound Gc \\
\hline Ethanol & G & G & G \\
\hline Methanol & G & G & G \\
\hline Cyclohexane & G & G & G \\
\hline n-Hexane & G & G & G \\
\hline Petroleum-Ether & G & G & G \\
\hline o-Xylene & S & S & S \\
\hline m-Xylene & S & S & S \\
\hline p-Xylene & S & S & S \\
\hline Ethanol/water $(4: 1)$ & P & G & P \\
\hline Toluene & S & S & S \\
\hline Ethyl acetate & S & S & S \\
\hline Benzene & S & S & S \\
\hline Diesel & G & G & G \\
\hline kerosene & G & G & G \\
\hline Crude oil & G & G & G \\
\hline Petrol & S & G & G \\
\hline Olive oil & G & G & G \\
\hline Castor oil & G & G & G \\
\hline Soybean oil & & G \\
\hline
\end{tabular}

G: gel; S: soluble; $\mathrm{P}=$ precipitation.

Table S1: Gelation abilities of Isoxazole Based Low Molecular Weight Gelators. 


\begin{tabular}{|l|l|l|l|l|}
\hline Solvent & Gelator & $\mathrm{G}^{\prime \prime}($ at $10 \mathrm{~Hz})$ & $\mathrm{G}^{\prime}($ at $10 \mathrm{~Hz})$ & Tan $\delta\left(\times 10^{-4}\right)$ \\
\hline Castor oil & $-\mathrm{C}_{16} \mathrm{H}_{33}(\mathbf{G c})$ & $826.7 \mathrm{~Pa}$ & $2301.3 \mathrm{~Pa}$ & 62.7 \\
\cline { 2 - 6 } & $-\mathrm{C}_{10} \mathrm{H}_{21}(\mathbf{G b})$ & $19.2 \mathrm{~Pa}$ & $85.4 \mathrm{~Pa}$ & 39.1 \\
\cline { 2 - 6 } & $-\mathrm{C}_{8} \mathrm{H}_{17}(\mathbf{G a})$ & $12.7 \mathrm{~Pa}$ & $61.8 \mathrm{~Pa}$ & 36.0 \\
\hline \multirow{5}{*}{ Ethanol } & $-\mathrm{C}_{16} \mathrm{H}_{33}(\mathbf{G c})$ & $1292 \mathrm{~Pa}$ & $4565 \mathrm{~Pa}$ & 49.3 \\
\cline { 2 - 5 } & $-\mathrm{C}_{10} \mathrm{H}_{21}(\mathbf{G b})$ & $2564.9 \mathrm{~Pa}$ & $6271.4 \mathrm{~Pa}$ & 71.3 \\
\cline { 2 - 5 } & $-\mathrm{C}_{8} \mathrm{H}_{17}(\mathbf{G a})$ & $5366.8 \mathrm{~Pa}$ & $13363.3 \mathrm{~Pa}$ & 69.7 \\
\hline
\end{tabular}

Table S2: Rheology data for isoxazole based gels extracted from Figure 2B-C in the manuscript.

\section{Experimental section:}

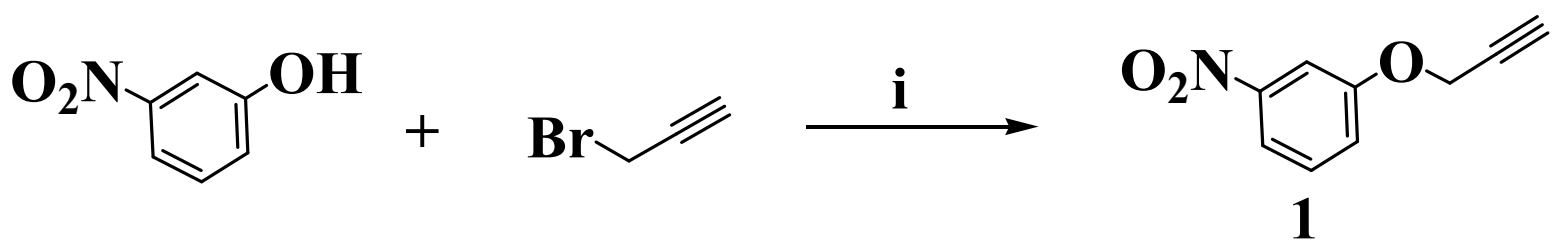

${ }^{a}$ Reaction Conditions: (i) $\mathrm{K} 2 \mathrm{CO} 3$, dry acetone, reflux, $6 \mathrm{~h}$.

Scheme S1: Syntheses of compound 1.

\section{Synthesis of compound 1 :}

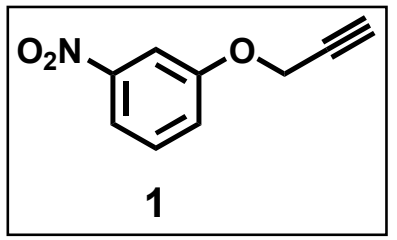

A mixture of $m$-nitrophenol (500 mg, $3.591 \mathrm{mmol})$, and anhydrous $\mathrm{K}_{2} \mathrm{CO}_{3}(495.56$ $\mathrm{mg}, 3.59 \mathrm{mmol})$ was taken in dry acetone $(20 \mathrm{~mL})$ under $\mathrm{N}_{2}$ and stirred at $60^{\circ} \mathrm{C}$ for 30 minutes, followed by addition of propargyl bromide $(0.272 \mathrm{ml}, 3.591 \mathrm{mmol})$. The reaction was continued at $60{ }^{\circ} \mathrm{C}$ for the next $6 \mathrm{~h}$ under $\mathrm{N}_{2}$ atmosphere. After completion, the reaction was stopped and concentrated under reduced pressure. The crude was extracted in ethyl acetate and dried over anhydrous $\mathrm{MgSO}_{4}$. The organic solvent was removed under reduced pressure and then the crude was purified further by flash column chromatography using silica gel as a solid stationary phase and EtOAc: Petroleum ether (5:95, v: v) as eluent to get compound 1 as yellowish solid. Yield $=98 \%$

${ }^{1} \mathbf{H}\left(400 \mathbf{M H z}, \mathbf{C D C l}_{3}\right)$ of compound 1: $\delta=7.87(\mathrm{~d}, J=8.3,1 \mathrm{H}), 7.83(1 \mathrm{H}, \mathrm{s}), 7.46(\mathrm{t}, J=8.2,1 \mathrm{H}),, 7.31(\mathrm{~d}, J$ $=10.0,1 \mathrm{H}), 4.78(\mathrm{~d}, J=2.4,2 \mathrm{H}),, 2.57(\mathrm{~s}, 1 \mathrm{H},) \mathrm{ppm}$.

${ }^{13} \mathbf{C}\left(\mathbf{1 0 1} \mathrm{MHz}, \mathbf{C D C l}_{3}\right)$ of compound 1: $\delta=157.93,149.13,130.07,121.93,116.59,109.53,77.32,76.67,56.30$ ppm.

The general procedure of the synthesis of compound 3a-c: 3 , 4-dihydroxybenzadeyde (1.0 equiv.) and anhydrous $\mathrm{K}_{2} \mathrm{CO}_{3}$ (4 equiv.) were taken in dry acetone under $\mathrm{N}_{2}$ and stirred at $60^{\circ} \mathrm{C}$ for 30 minutes. To this mixture 1-bromoalkane (2.5 equiv.) was added, and the reaction was continued at $60^{\circ} \mathrm{C}$ for the next 12 hours under $\mathrm{N}_{2}$ atmosphere. After completion of the reaction, the crude was extracted with ethyl acetate. The organic layer was dried over anhydrous $\mathrm{MgSO}_{4}$, removed under reduced pressure to get the crude product which was further purified by silica gel column chromatography using ethyl acetate and petroleum ether to get a pure product as colorless solid. 


\section{Synthesis of compound 3a:}

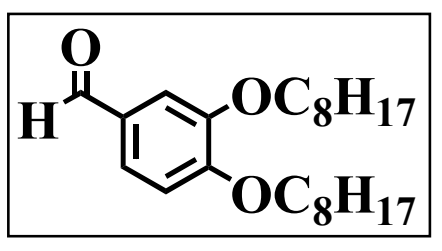

A mixture of 3,4- dihydroxybenzadeyde $(1.0 \mathrm{~g}, 7.24 \mathrm{mmol})$ and anhydrous $\mathrm{K}_{2} \mathrm{CO}_{3}(4.00 \mathrm{~g}, 28.96 \mathrm{mmol})$ in $100 \mathrm{ml}$ dry acetone was reacted with 1bromoctane $(3.12 \mathrm{ml}, 18.10 \mathrm{mmol})$ according to the procedure mention above to get $1.60 \mathrm{~g}$ of compound $3 \mathrm{a}$ having yield of $70 \%$.

${ }^{1} \mathrm{H}-\mathrm{NMR}\left(400 \mathrm{MHz} \mathrm{CDCl}_{3}\right)$ of compound 3a: $\delta=9.83(\mathrm{~s}, 1 \mathrm{H}), 7.41(\mathrm{~d}, J=$ $8 \mathrm{~Hz} 1 \mathrm{H}), 7.40(\mathrm{~s}, 1 \mathrm{H}), 6.95(\mathrm{~d}, J=8 \mathrm{~Hz}, 1 \mathrm{H}), 4.09-4.03(\mathrm{~m}, 4 \mathrm{H}), 1.89-1.80(\mathrm{~m}, 4 \mathrm{H}), 1.50-1.45(\mathrm{~m}, 4 \mathrm{H}), 1.35-1.29$ $(\mathrm{m}, 16 \mathrm{H}), 0.89$ ( $\mathrm{t}, J=6.8 \mathrm{~Hz}, 6 \mathrm{H}) \mathrm{ppm}$.

${ }^{13} \mathbf{C}\left(\mathbf{1 0 1} \mathbf{M H z}, \mathbf{C D C l}_{3}\right)$ of compound 3a: $\delta=190.99,154.68,149.44,129.87,126.58,111.75,110.96,69.13$, $31.78,29.15,25.97,22.65,14.08 \mathrm{ppm}$.

\section{Synthesis of compound 3b:}

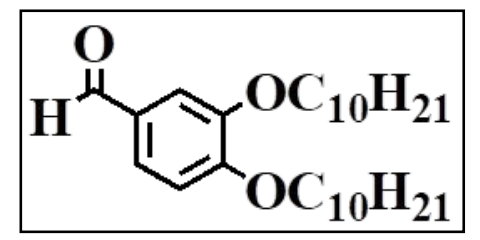

A mixture of 3,4-dihydroxybenzadeyde $(1.0 \mathrm{~g}, 7.24 \mathrm{mmol})$ and anhydrous $\mathrm{K}_{2} \mathrm{CO}_{3}(4.00 \mathrm{~g}, 28.96 \mathrm{mmol})$ in $100 \mathrm{ml}$ dry acetone was reacted with 1bromodecane $(3.75 \mathrm{~mL}, 18.10 \mathrm{mmol})$ according to the procedure mention above to get $1.9 \mathrm{~g}$ of compound $\mathbf{3 b}$ having yield of $70 \%$.

${ }^{1}$ H-NMR (400 $\left.\mathrm{CDCl}_{3}\right)$ ofcompound 3b: $\delta=9.83(\mathrm{~s}, 1 \mathrm{H}), 7.41(\mathrm{~d}, \mathrm{~J}=8.4 \mathrm{~Hz}$, $1 \mathrm{H}), 7.40(\mathrm{~s}, 1 \mathrm{H}), 6.95(\mathrm{~d}, \mathrm{~J}=8.4 \mathrm{~Hz}, 1 \mathrm{H}), 4.09-4.03(\mathrm{~m}, 4 \mathrm{H}), 1.90-1.80(\mathrm{~m}, 4 \mathrm{H}), 1.49-1.44(\mathrm{~m}, 4 \mathrm{H}), 1.36-1.27$ $(\mathrm{m}, 24 \mathrm{H}), 0.88(\mathrm{t}, J=6.8 \mathrm{~Hz}, 6 \mathrm{H}) \mathrm{ppm}$.

${ }^{13} \mathbf{C}\left(\mathbf{1 0 1} \mathbf{M H z}, \mathbf{C D C l}_{3}\right)$ of compound 3b: $\delta=190.98,154.68,149.44,129.87,126.57,111.75,110.96,69.11$, $31.90,29.54,29.33,29.02,25.98,22.67,14.09 \mathrm{ppm}$.

\section{Synthesis of compound 3c:}

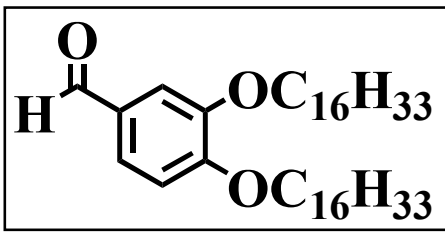

A mixture of 3,4-dihydroxybenzadeyde $(1.00 \mathrm{~g}, 7.24 \mathrm{mmol})$ and anhydrous $\mathrm{K}_{2} \mathrm{CO}_{3}(4.00 \mathrm{~g}, 28.96 \mathrm{mmol})$ were taken in $100 \mathrm{~mL}$ dry acetone under $\mathrm{N}_{2}$ and was allowed to react with 1-bromo hexadecane $(5.53 \mathrm{~mL}, 18.10 \mathrm{mmol})$ according to the procedure mention above to get $2.6 \mathrm{~g}$ of compound $\mathbf{3 b}$ having yield of $70 \%$.

${ }^{1} \mathrm{H}-\mathrm{NMR}\left(400 \mathrm{MHz} \mathrm{CDCl}_{3}\right)$ of compound 3c: $\delta=9.86(\mathrm{~s}, \mathrm{H}), 7.44(\mathrm{~d}, J=8.4 \mathrm{~Hz}, 1 \mathrm{H}), 7.42(\mathrm{~s}, \mathrm{H}), 6.98(\mathrm{~d}, J=$ $8.0 \mathrm{~Hz}, 1 \mathrm{H}), 4.12-4.06(\mathrm{~m}, 4 \mathrm{H}), 1.92-1.83(\mathrm{~m}, 4 \mathrm{H}), 1.52-1.47(\mathrm{~m}, 4 \mathrm{H}), 1.38-1.25(\mathrm{~m}, 48 \mathrm{H}), 0.91(\mathrm{t}, J=6.8 \mathrm{~Hz}$, 6H) $\mathrm{ppm}$.

${ }^{13} \mathbf{C}\left(\mathbf{1 0 1} \mathbf{~ M H z}, \mathbf{C D C l}_{3}\right)$ of compound 3c: $\delta=190.98,154.68,149.44,129.87,126.57,111.75,110.97,69.14$, 31.92 , 29.66, 29.36, 29.02, 25.98, 22.68, $14.10 \mathrm{ppm}$.

General procedure towards the synthesis of compound 4a-c: $1 \mathrm{~g}$ of compound 3a-c (1.0 equiv.) was dissolved in $40 \mathrm{~mL}$ ethanol and an excess amount of hydroxylamine hydrochloric acid was added. The reaction was allowed to continue at room temperature for $2 \mathrm{~h}$ and monitored by TLC. After completion, the solvent was evaporated under reduced pressure and then deionized water was added to the crude to obtain white precipitation, which was then filtered and purified further by column chromatography. 


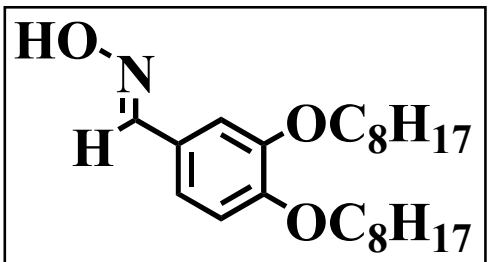

Compound 3a (1.0g $1.98 \mathrm{~mol})$ was taken in $40 \mathrm{~mL}$ ethanol and allowed to react with excess amount of hydroxylamine hydrochloric acid according to the procedure mention above to get $0.95 \mathrm{~g}$ of compound $\mathbf{4 a}$. Yield is $94 \%$.

${ }^{1} \mathrm{H}-\mathrm{NMR}\left(500 \mathrm{MHz}_{\mathbf{C D C l}}\right.$ ) of compound 4a: $\delta=8.05(\mathrm{~s}, 1 \mathrm{H}), 7.64(\mathrm{~s}$, $1 \mathrm{H}), 7.20(\mathrm{~s}, 1 \mathrm{H}), 7.00(\mathrm{~d}, J=8 \mathrm{~Hz}, 1 \mathrm{H}), 6.84(\mathrm{~d}, J=8 \mathrm{~Hz}, 1 \mathrm{H}), 4.01(\mathrm{t}, J=$ $6.5 \mathrm{~Hz}, 4 \mathrm{H},) \quad 1.86-1.79(\mathrm{~m}, 4 \mathrm{H}), 1.50-1.43(\mathrm{~m}, 4 \mathrm{H}), 1.32-1.28(\mathrm{~m}, 16 \mathrm{H}), 0.88(\mathrm{t}, J=6.8,6 \mathrm{H}) \mathrm{ppm}$.

${ }^{13} \mathbf{C}\left(\mathbf{1 0 1} \mathbf{M H z}, \mathbf{C D C l}_{3}\right)$ of compound 4a: $\delta=150.94,150.30,149.31,124.69,121.54,112.82,110.37,69.12$, $31.84,29.26,26.01,22.69,14.13 \mathrm{ppm}$.

\section{Synthesis of compound $4 \mathrm{~b}$ :}

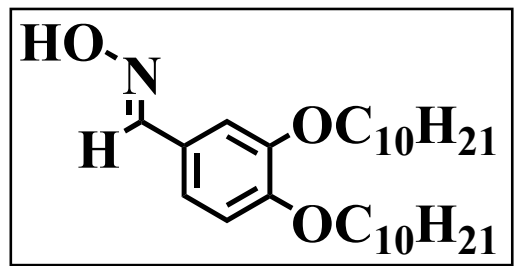

Compound 3b (1.0 g $1.98 \mathrm{~mol})$ was reacted with excess amount of hydroxylamine hydrochloric acid in $40 \mathrm{~mL}$ ethanol according to the general procedure mention above to yield $1 \mathrm{~g}$ of compound $\mathbf{4 b}$ (yield $97 \%$ ).

${ }^{1} \mathrm{H}-\mathrm{NMR}\left(400 \mathrm{MHz}, \mathrm{CDCl}_{3}\right.$ ) compound 4b: $\delta=8.06(\mathrm{~s}, 1 \mathrm{H}), 7.20(\mathrm{~s}, 1 \mathrm{H})$, $7.00(\mathrm{~d}, J=8.3 \mathrm{~Hz}, 1 \mathrm{H}),, 6.84(\mathrm{~d}, J 8.3 \mathrm{~Hz}, 1 \mathrm{H}), 4.01(\mathrm{t}, J=6.6 \mathrm{~Hz}, 4 \mathrm{H}), 1.86$

$-1.78(\mathrm{~m}, 4 \mathrm{H}), 1.45(\mathrm{~m}, 4 \mathrm{H}), 1.39-1.23(\mathrm{~m}, 26 \mathrm{H}), 0.88(\mathrm{t}, J=6.8 \mathrm{~Hz}, 6 \mathrm{H}) \mathrm{ppm}$.

${ }^{13} \mathbf{C}\left(\mathbf{1 0 1} \mathbf{M H z}, \mathbf{C D C l}_{3}\right)$ of compound 4b: $\delta=151.18,150.60,149.52,124.83,121.81,112.98,110.47,69.33$, $32.16,29.74,29.38,26.24,22.94,14.37$ ppm.

\section{Synthesis of compound $4 c$ :}

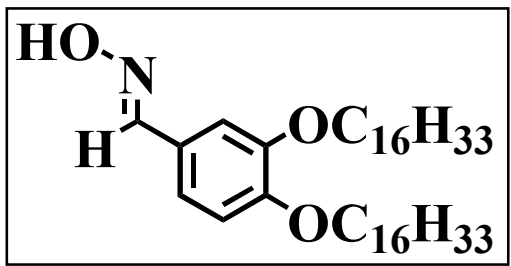

Compound 3c (1.0 g $1.98 \mathrm{~mol})$ was reacted with an excess amount of hydroxylamine hydrochloric acid in $40 \mathrm{~mL}$ ethanol according to the general procedure mention above to yield $0.9 \mathrm{~g}$ of compound $\mathbf{4 c}$ (yield $96 \%$ ).

${ }^{1} \mathrm{H}-\mathrm{NMR}\left(400 \mathrm{MHz}, \mathrm{CDCl}_{3}\right)$ compound 4c: $\delta=8.05(\mathrm{~s}, 1 \mathrm{H}), 7.20(\mathrm{~s}, 1 \mathrm{H})$, $7.00(\mathrm{~d}, J=8.3 \mathrm{~Hz}, 1 \mathrm{H}), 6.84(\mathrm{~d}, J=8.3 \mathrm{~Hz}, 1 \mathrm{H}), 4.01(\mathrm{t}, J=6.6 \mathrm{~Hz}, 4 \mathrm{H}), 1.87-1.77(\mathrm{~m}, 8 \mathrm{H}), 1.51-1.40(\mathrm{~m}, 4 \mathrm{H})$, $1.28(\mathrm{~m}, 48 \mathrm{H}), 0.88(\mathrm{t}, J=6.8 \mathrm{~Hz}, 6 \mathrm{H}) \mathrm{ppm}$.

${ }^{13} \mathbf{C}\left(\mathbf{1 0 1} \mathbf{M H z}, \mathbf{C D C l}_{3}\right)$ of compound 4c: $\delta=150.94,150.31,149.34,124.80,121.46,112.91,110.42,69.13$, $65.84,31.91,30.89,29.65,29.26,25.98,22.67,15.23,14.08 \mathrm{ppm}$.

General procedure towards the syntheses of compound Ga-c: Compound 4a-c (1 equiv.) and compound 1 (2 equiv.) were taken together in dry DCM and stirred for 10 minutes. An excess amount of $\mathrm{NaOCl}$ was added into the reaction mixture and the reaction was continued for an hour. After completion of the reaction, DCM was evaporated to get crude solid which was further purified by column chromatography using silica gel as a solid stationary phase.

\section{Synthesis of compound Ga:}

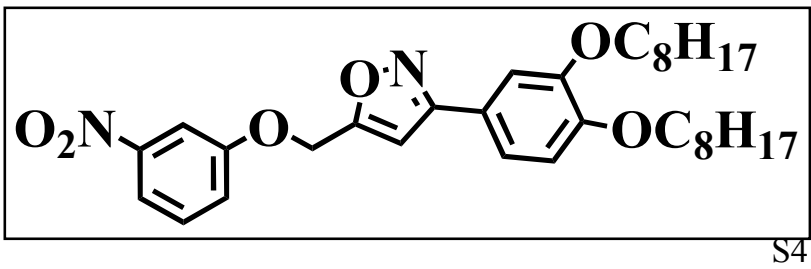

A mixture of compound $4 \mathbf{a}(500 \mathrm{mg}, 1.325 \mathrm{mmol})$ and compound 1 (384.60 mg, $2.66 \mathrm{mmol}$ ) were taken together in $30 \mathrm{~mL}$ dry DCM and stirred for 10 minutes at room temperature. An excess amount of 
$\mathrm{NaOCl}$ was added into the reaction mixture and the reaction was continued according to the procedure mention above to get the pure Ga having yield of $430 \mathrm{mg}(73 \%)$.

${ }^{1} \mathrm{H}-\mathrm{NMR}\left(400 \mathrm{MHz} \mathrm{CDCl}_{3}\right)$ of compound Ga: $\delta=7.90(\mathrm{~d}, J=9.2 \mathrm{~Hz}, 1 \mathrm{H}), 7.86(\mathrm{~s}, 1 \mathrm{H}), 7.48(\mathrm{t}, J=8.0 \mathrm{~Hz}, 1 \mathrm{H})$ $7.40(\mathrm{~s}, 1 \mathrm{H}), 7.32(\mathrm{~d}, J=8.4 \mathrm{~Hz}, 1 \mathrm{H}), 7.26(\mathrm{~d}, J=8.4 \mathrm{~Hz}, 1 \mathrm{H}), 6.92(\mathrm{~d}, J=8.0 \mathrm{~Hz}, 1 \mathrm{H}), 5.27(\mathrm{~s}, 2 \mathrm{H}), 4.07-4.02(\mathrm{~m}$, 4H), $1.88-1.80(\mathrm{~m}, 4 \mathrm{H}), 1.51-1.44(\mathrm{~m}, 4 \mathrm{H}), 1.33-1.29(\mathrm{~m}, 16 \mathrm{H}), 0.89(\mathrm{t}, J=6.4 \mathrm{~Hz}, 6 \mathrm{H}) \mathrm{ppm}$.

${ }^{13} \mathbf{C}\left(\mathbf{1 0 1} \mathbf{M H z}, \mathbf{C D C l}_{3}\right)$ of compound Ga: $\delta=166.70,162.45,158.23,151.03,149.43,30.32,121.62,121.03$, 120.04 , 116.87, 113.23, 111.66, 109.40, 101.82, 69.37, 69.16, 61.68, 31.81, 29.36, 26.00, 22.66, 14.09 ppm.

HRMS $(E S I+, m / z,[M+H]+)$ calculated for $\mathrm{C}_{32} \mathrm{H}_{44} \mathrm{~N}_{2} \mathrm{O}_{6}: 552.3199$ and Found: 553.32876

\section{Synthesis of compound Gb:}

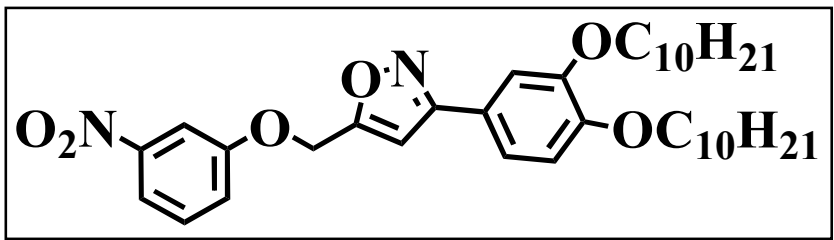

A mixture of compound $\mathbf{4 b}(500 \mathrm{mg}, 1.154 \mathrm{mmol})$ and compound 1 (334.85 $\mathrm{mg}, 2.307 \mathrm{mmol}$ ) were taken together in $30 \mathrm{~mL}$ dry DCM and stirred for 10 minutes at room temperature. An excess amount of $\mathrm{NaOCl}$ was added into the reaction mixture and the reaction was continued according to the procedure mention above to get the pure $430 \mathrm{mg}$ of $\mathbf{G b}$ having yield of $72 \%$

${ }^{1} \mathrm{H}-\mathrm{NMR}\left(400 \mathrm{MHz}_{\mathbf{C D C l}}\right)$ of compound Gb: $\delta=7.90(\mathrm{~d}, J=8.0 \mathrm{~Hz}, 1 \mathrm{H}), 7.86(\mathrm{~s}, 1 \mathrm{H}), 7.49(\mathrm{t}, J=8.2 \mathrm{~Hz}, 1 \mathrm{H})$ $7.40(\mathrm{~s}, 1 \mathrm{H}), 7.32(\mathrm{~d}, J=8.4 \mathrm{~Hz}, 1 \mathrm{H}), 7.26(\mathrm{~d}, J=8 \mathrm{~Hz}, 1 \mathrm{H}), 6.92(\mathrm{~d}, J=8.4 \mathrm{~Hz}, 1 \mathrm{H}), 6.63(\mathrm{~s}, 1 \mathrm{H}), 5.28(\mathrm{~s}, 2 \mathrm{H})$, 4.07-4.02 (m, 4H), 1.87-1.80 (m, 4H), 1.51-1.44(m, 4H), 1.36-1.27 (m, 24H), $0.88(\mathrm{t}, J=6.4 \mathrm{~Hz}, 6 \mathrm{H}) \mathrm{ppm}$.

${ }^{13} \mathbf{C}\left(101 \mathrm{MHz}, \mathbf{C D C l}_{3}\right)$ of compound $\mathbf{G b}: \delta=166.70,162.44,158.23,151.03,149.43,130.31,121.62,121.04$, $120.04,116.87,113.23,111.66,109.40,101.82,69.36,69.16,61.68,31.90,29.57,29.26,26.00,22.68,14.10 \mathrm{ppm}$

HRMS $\left(\mathrm{ESI}^{+}, \mathrm{m} / \mathrm{z},[\mathrm{M}+\mathrm{H}]^{+}\right.$) calculated for $\mathrm{C}_{36} \mathrm{H}_{52} \mathrm{~N}_{2} \mathrm{O}_{6}: 608.3825$ and Found: 609.39108

\section{Synthesis of compound Gc:}

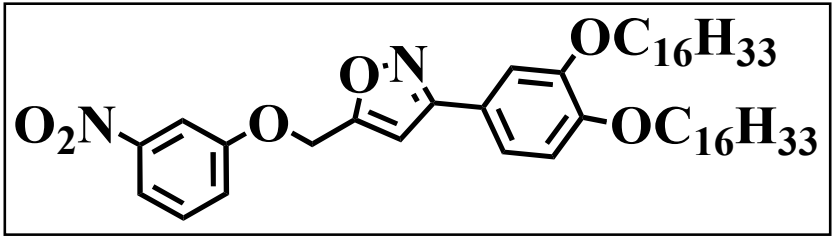

A mixture of compound $4 \mathrm{c}(500 \mathrm{mg}, 0.83 \mathrm{mmol})$ and compound 1 ( $2 \mathrm{mg}, 1.66 \mathrm{mmol})$ were taken together in $30 \mathrm{ml}$ dry DCM and stirred for 10 minutes at room temperature. An excess amount of $\mathrm{NaOCl}$ was added into the reaction mixture and the reaction was continued according to the procedure mention above to get $440 \mathrm{mg}$ of the pure Gc having yield of $77 \%$.

${ }^{1} \mathrm{H}$ NMR (400 MHz CDCl$\left.)_{3}\right)$ of compound Gc : $\delta 7.90(\mathrm{~d}, J=8 \mathrm{~Hz}, 1 \mathrm{H}), 7.86(\mathrm{~s}, 1 \mathrm{H}), 7.48(\mathrm{t}, J=8.2 \mathrm{~Hz}, 1 \mathrm{H}$,) $7.40(\mathrm{~s}, 1 \mathrm{H}), 7.32(\mathrm{~d}, J=8.4 \mathrm{~Hz}, 1 \mathrm{H}), 7.26(\mathrm{~d}, J=8 \mathrm{~Hz}, 1 \mathrm{H}), 6.91(\mathrm{~d}, J=8.4 \mathrm{~Hz}, 1 \mathrm{H}), 6.63(\mathrm{~s}, 1 \mathrm{H}), 5.27(\mathrm{~s}, 2 \mathrm{H})$, 4.07-4.02 (m, 4H), 1.87-1.80 (m, 4H), 1.51-1.44 (m, 4H), 1.35-1.26 (m, 48H), 0.89 (t, J=6.4Hz, 6H) ppm.

${ }^{13} \mathbf{C}\left(\mathbf{1 0 1} \mathbf{~ M H z}, \mathbf{C D C l}_{3}\right)$ of compound Gc: $\delta=162.44,158.24,151.03,149.44,130.31,121.61,121.04,120.04$, $116.87,101.81,69.37,61.68,31.92,29.67,29.36,26.01,22.69,14.11 \mathrm{ppm}$.

HRMS (ESI ${ }^{+}, \mathrm{m} / \mathrm{z},[\mathrm{M}+\mathrm{H}]^{+}$) calculated for $\mathrm{C}_{48} \mathrm{H}_{76} \mathrm{~N}_{2} \mathrm{O}_{6}: 609.3817$ and Found: 609.39108 


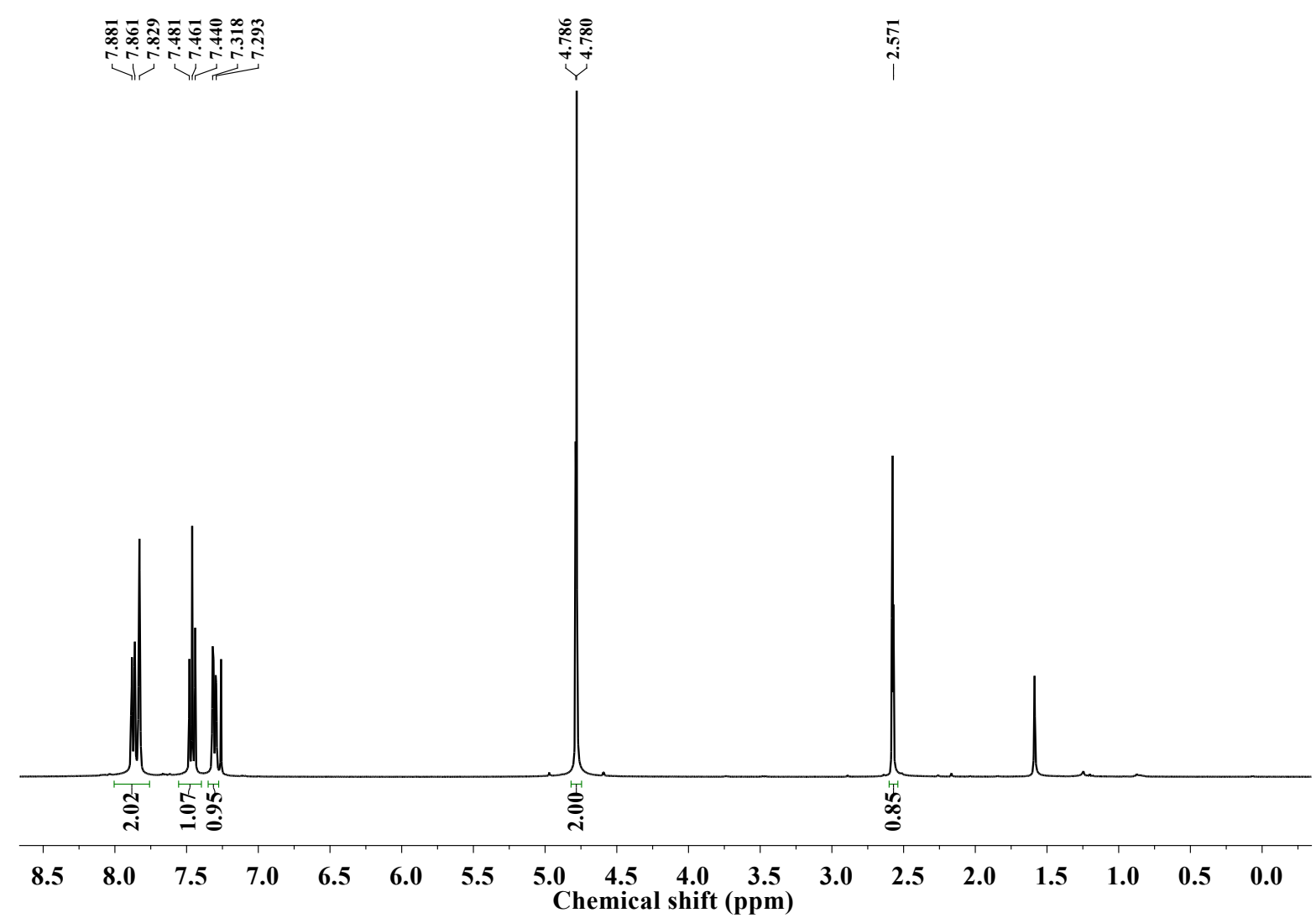

Figure S1: ${ }^{1} \mathrm{H}$ NMR spectrum of compound 1 in $\mathrm{CDCl}_{3}$ recorded at $298{ }^{\circ} \mathrm{K}$.

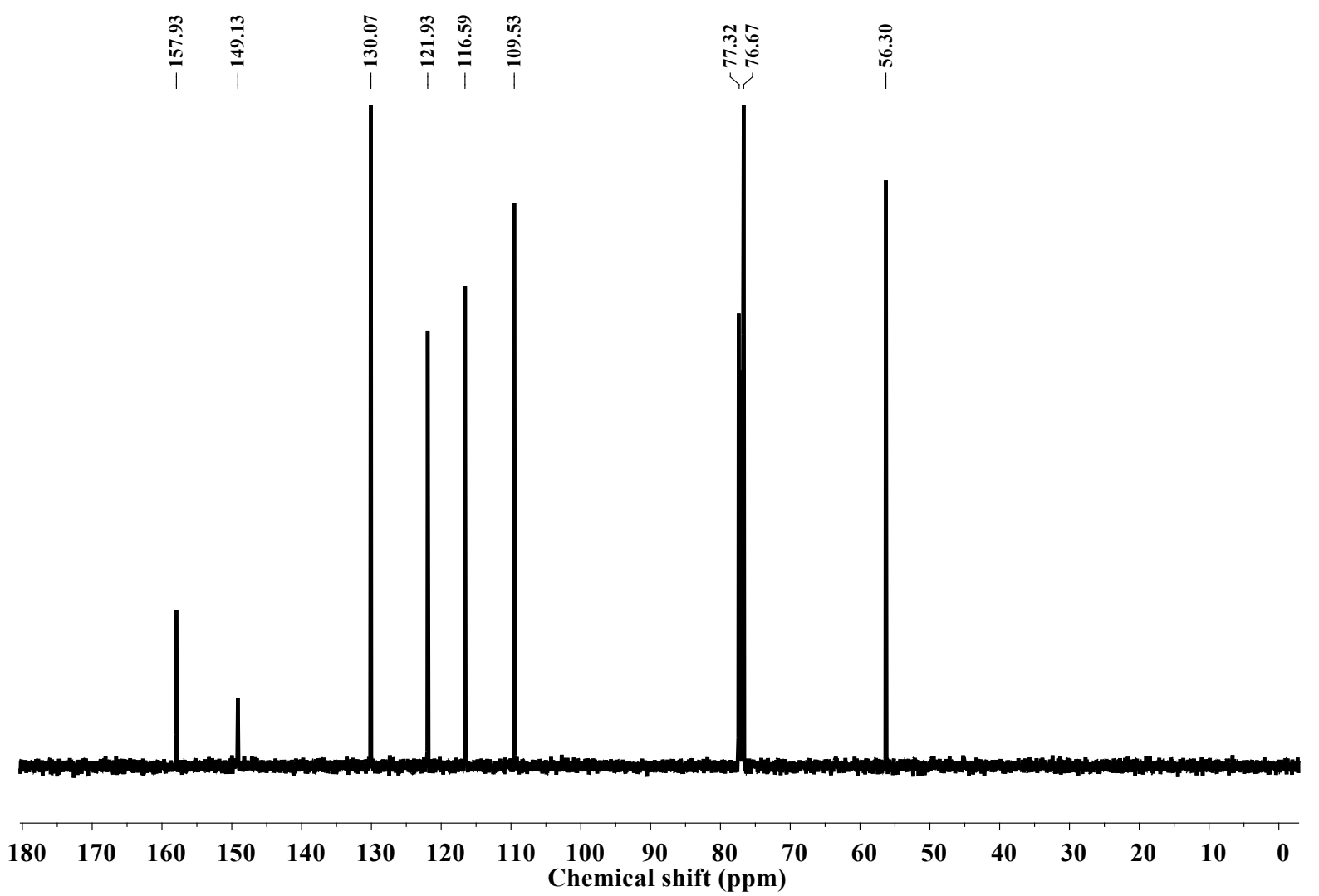

Figure S2: ${ }^{13} \mathrm{C}$ NMR spectrum of 1 in $\mathrm{CDCl}_{3}$ recorded at $298^{\circ} \mathrm{K}$. 


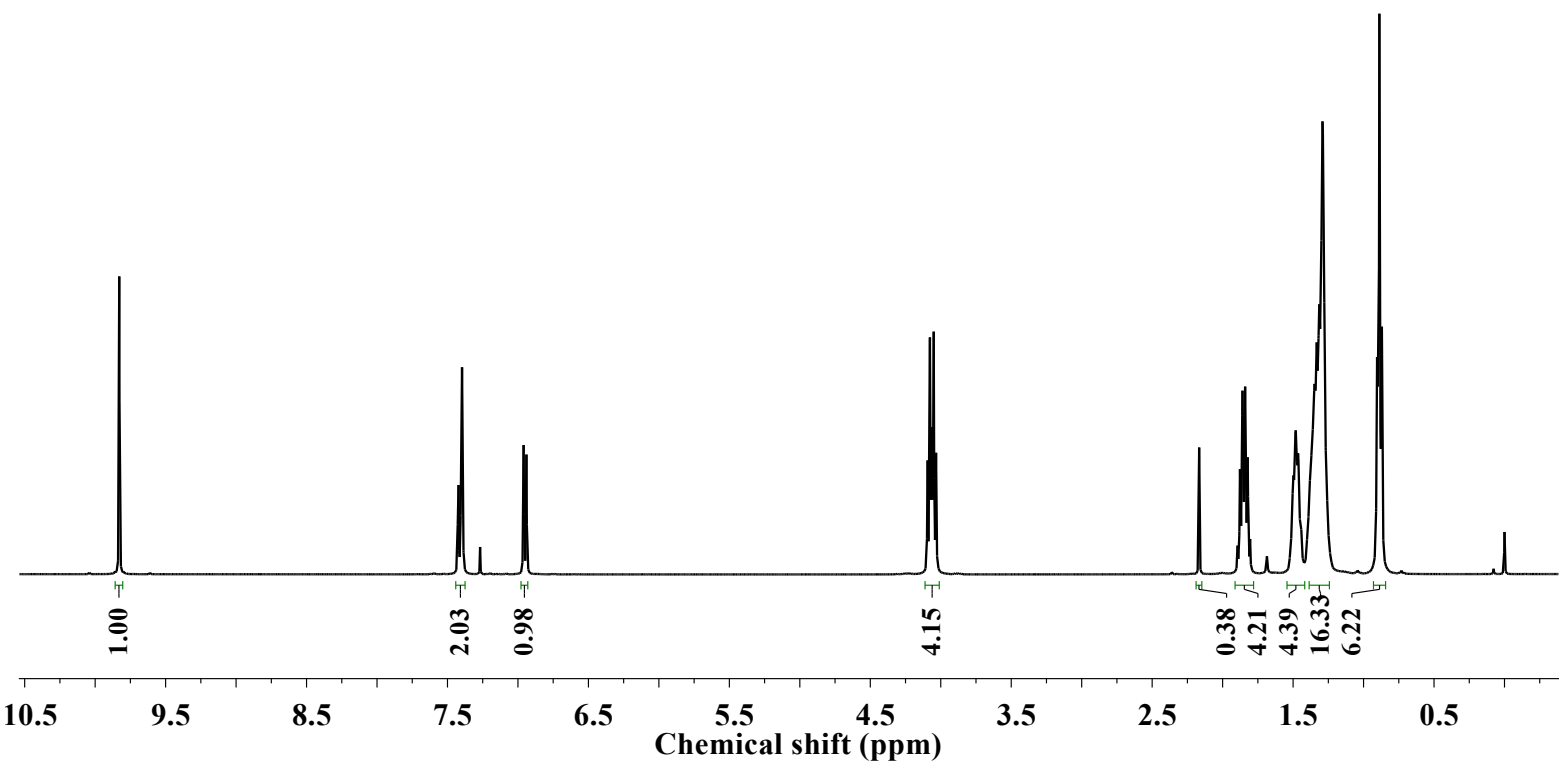

Figure S3: ${ }^{1} \mathrm{H}$ NMR spectrum of 3a in $\mathrm{CDCl}_{3}$ recorded at $298{ }^{\circ} \mathrm{K}$.

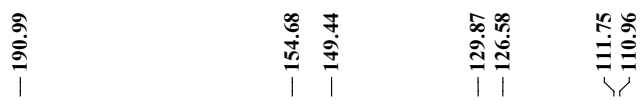

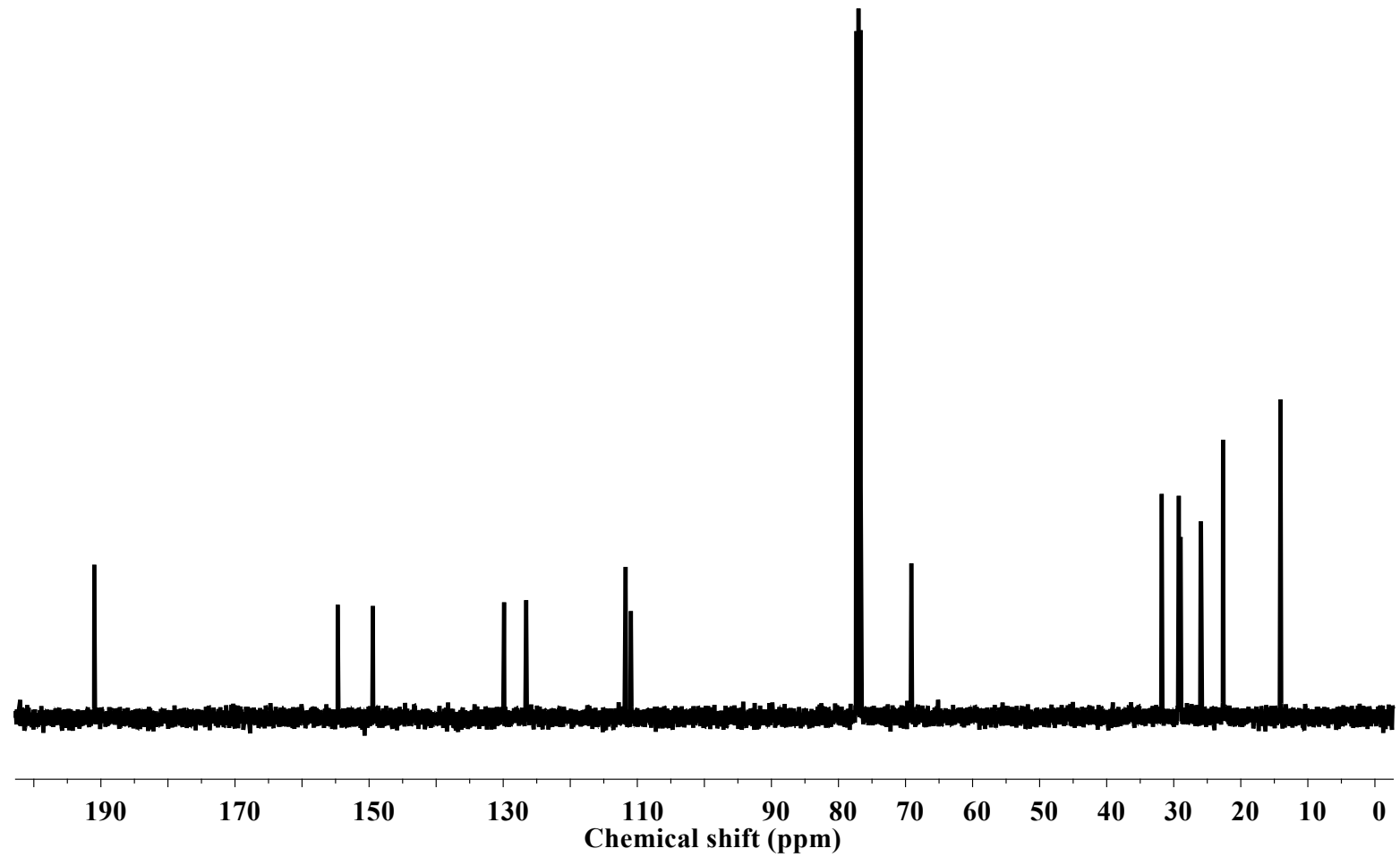

Figure $\mathrm{S} 4:{ }^{13} \mathrm{C}$ NMR spectrum of $3 \mathrm{a}$ in $\mathrm{CDCl}_{3}$ recorded at $298^{\circ} \mathrm{K}$. 


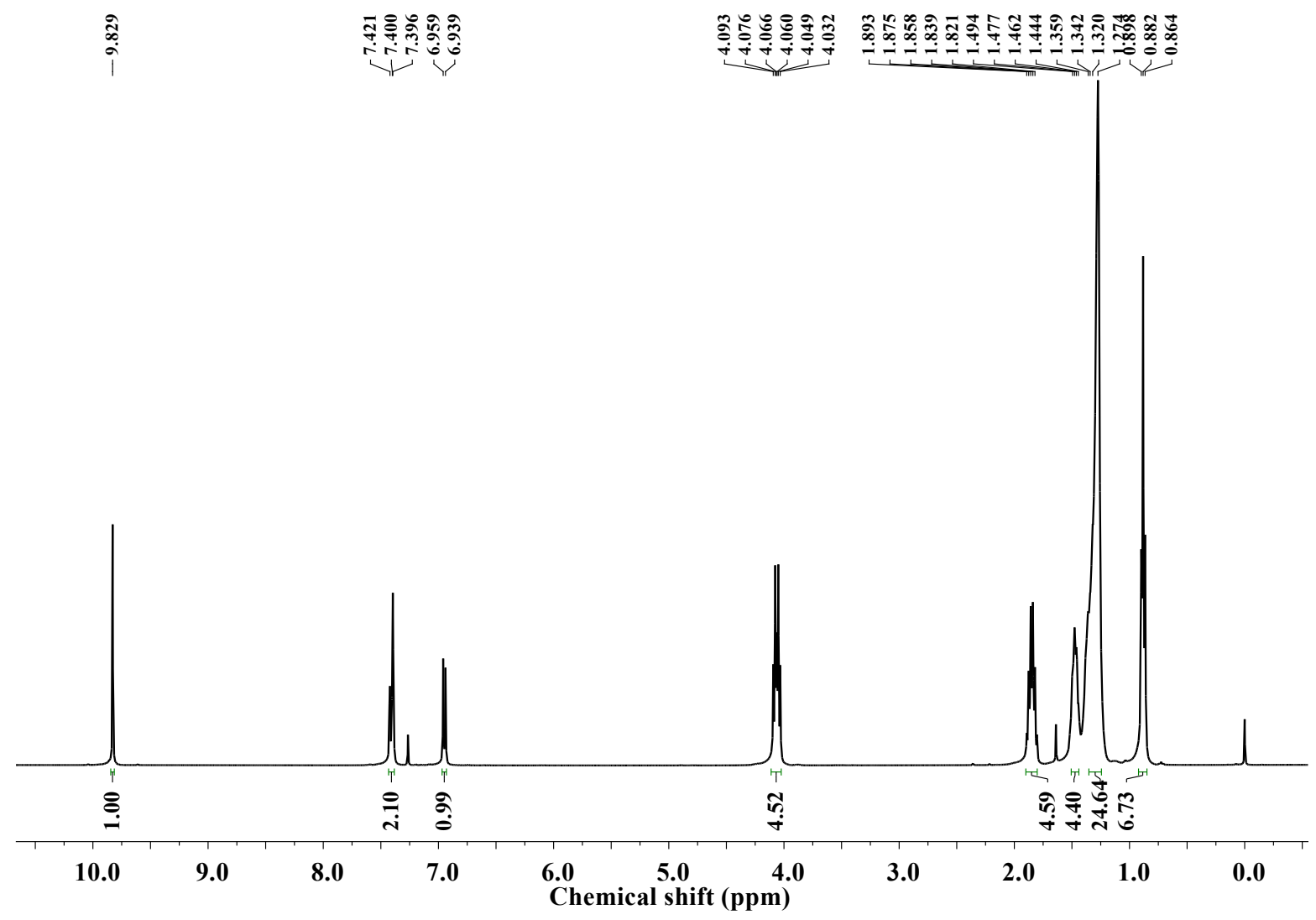

Figure S5: ${ }^{1} \mathrm{H}$ NMR spectrum of $3 \mathrm{~b}$ in $\mathrm{CDCl}_{3}$ recorded at $298^{\circ} \mathrm{K}$.
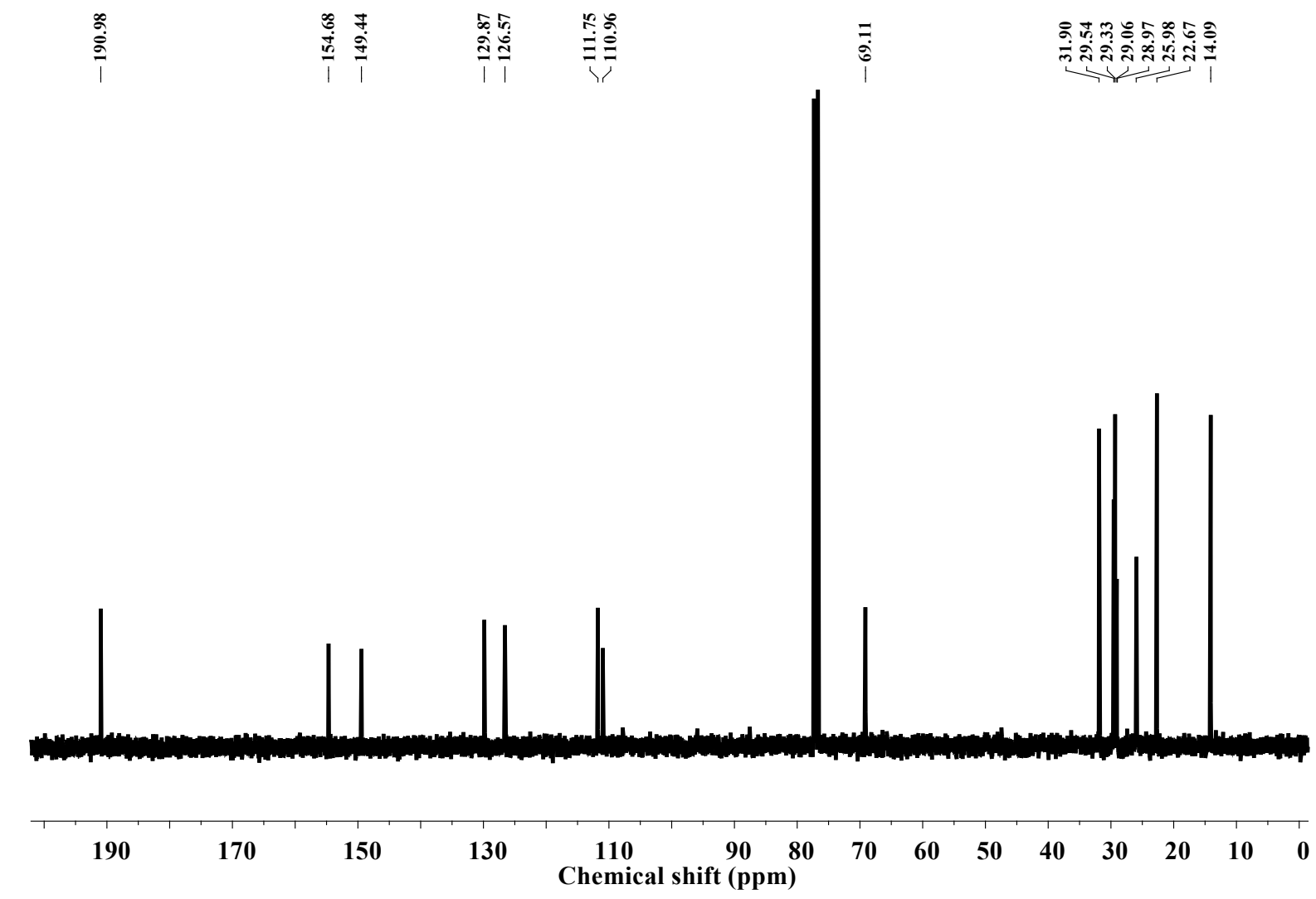

Figure S6: ${ }^{13} \mathrm{C}$ NMR spectrum of $3 \mathrm{~b}$ in $\mathrm{CDCl}_{3}$ recorded at $298{ }^{\circ} \mathrm{K}$. 


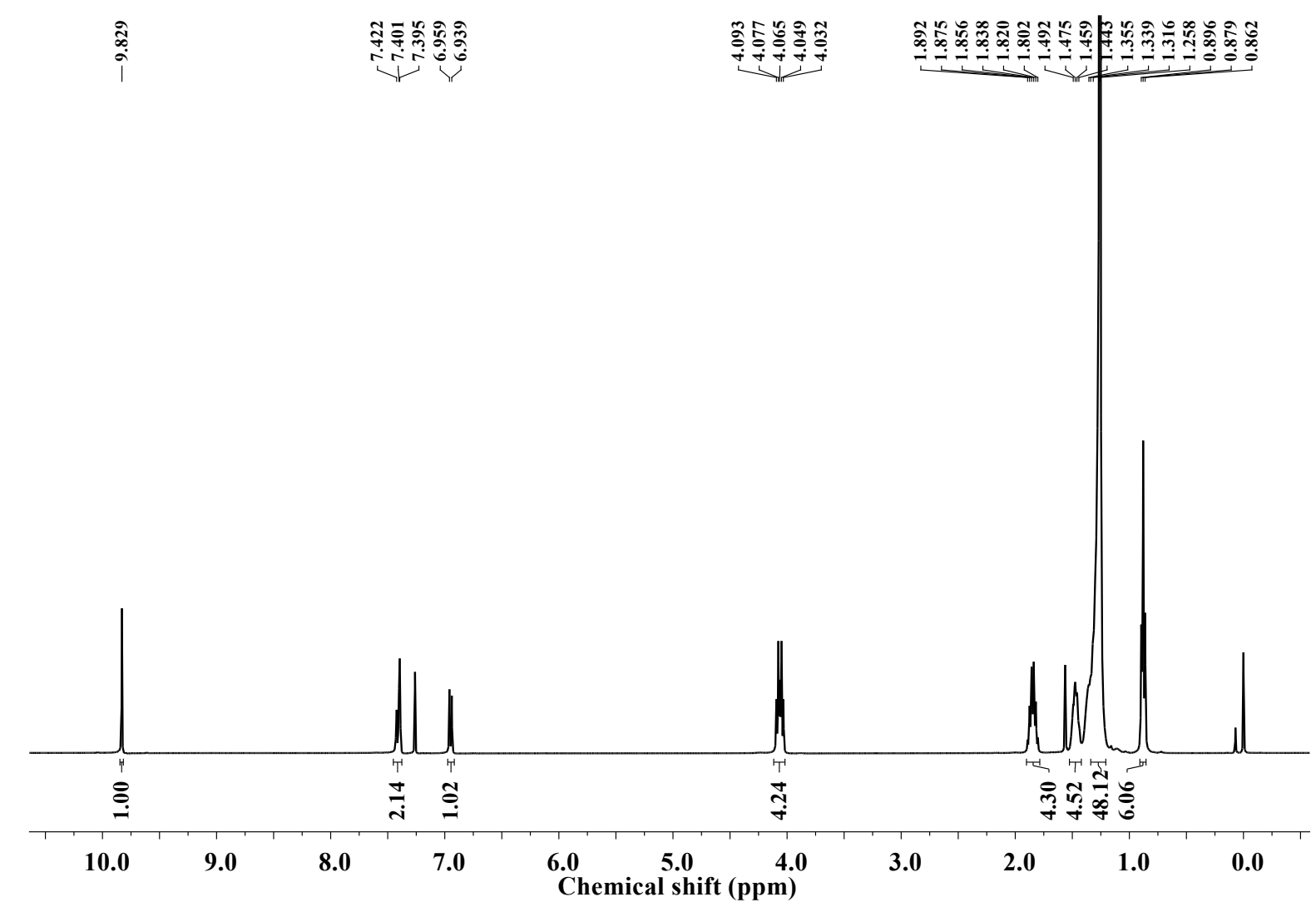

Figure $\mathrm{S7}:{ }^{1} \mathrm{H} \mathrm{NMR}$ spectrum of $3 \mathrm{c}$ in $\mathrm{CDCl}_{3}$ recorded at $298^{\circ} \mathrm{K}$.

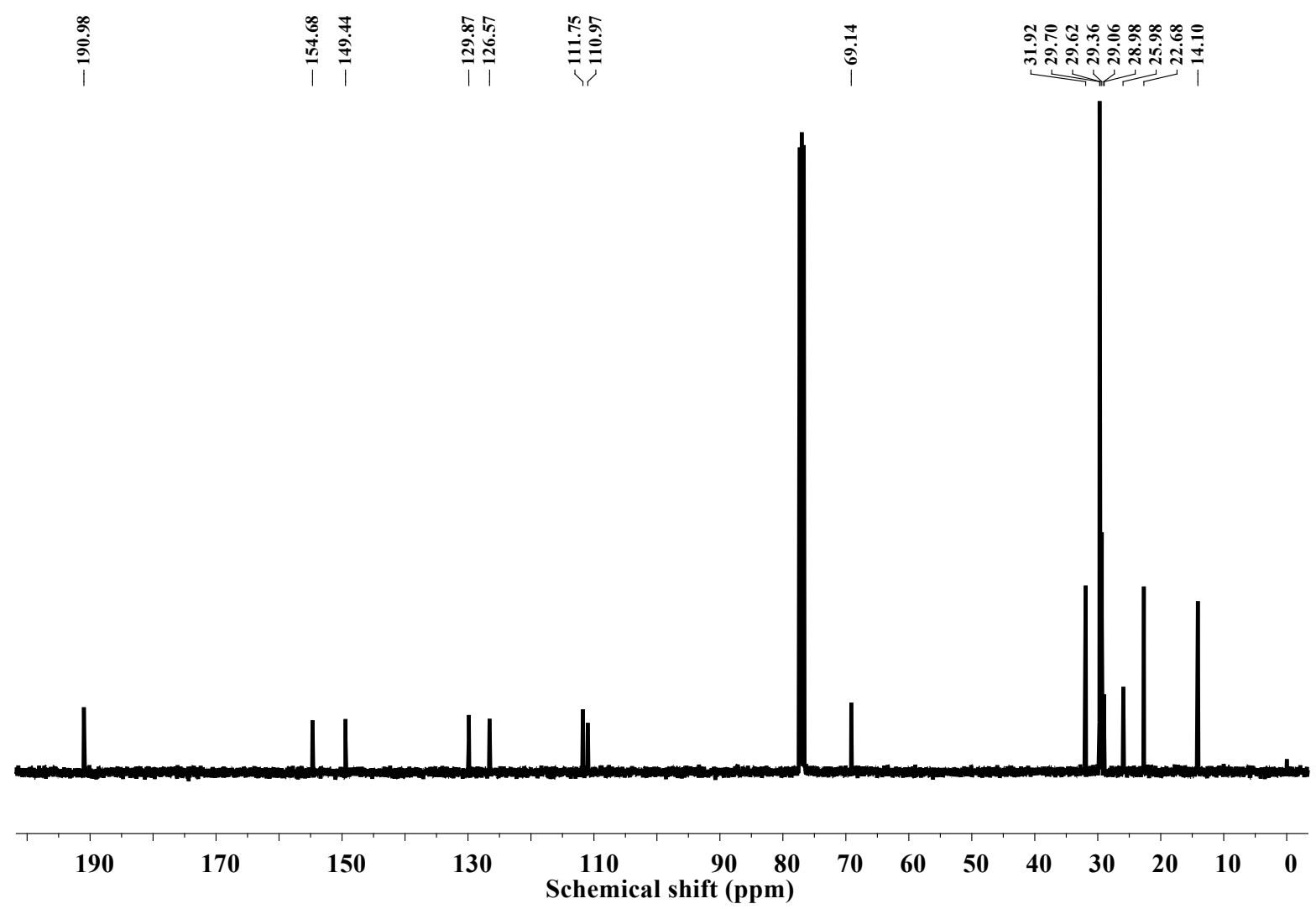

Figure $\mathrm{S8}:{ }^{13} \mathrm{C}$ NMR spectrum of $3 \mathrm{c}$ in $\mathrm{CDCl}_{3}$ recorded at $298^{\circ} \mathrm{K}$. 


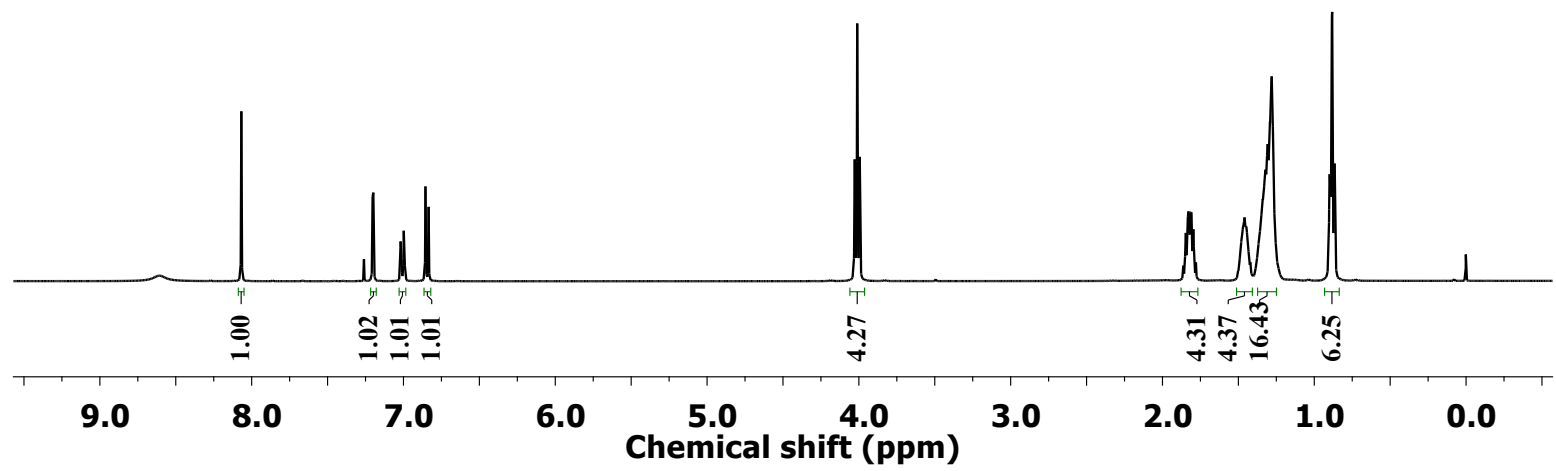

Figure S9: ${ }^{1} \mathrm{H}$ NMR spectrum of $4 a$ in $\mathrm{CDCl}_{3}$ recorded at $298{ }^{\circ} \mathrm{K}$.

\begin{tabular}{|c|c|c|}
\hline 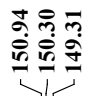 & 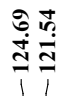 & 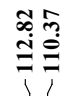 \\
\hline
\end{tabular}

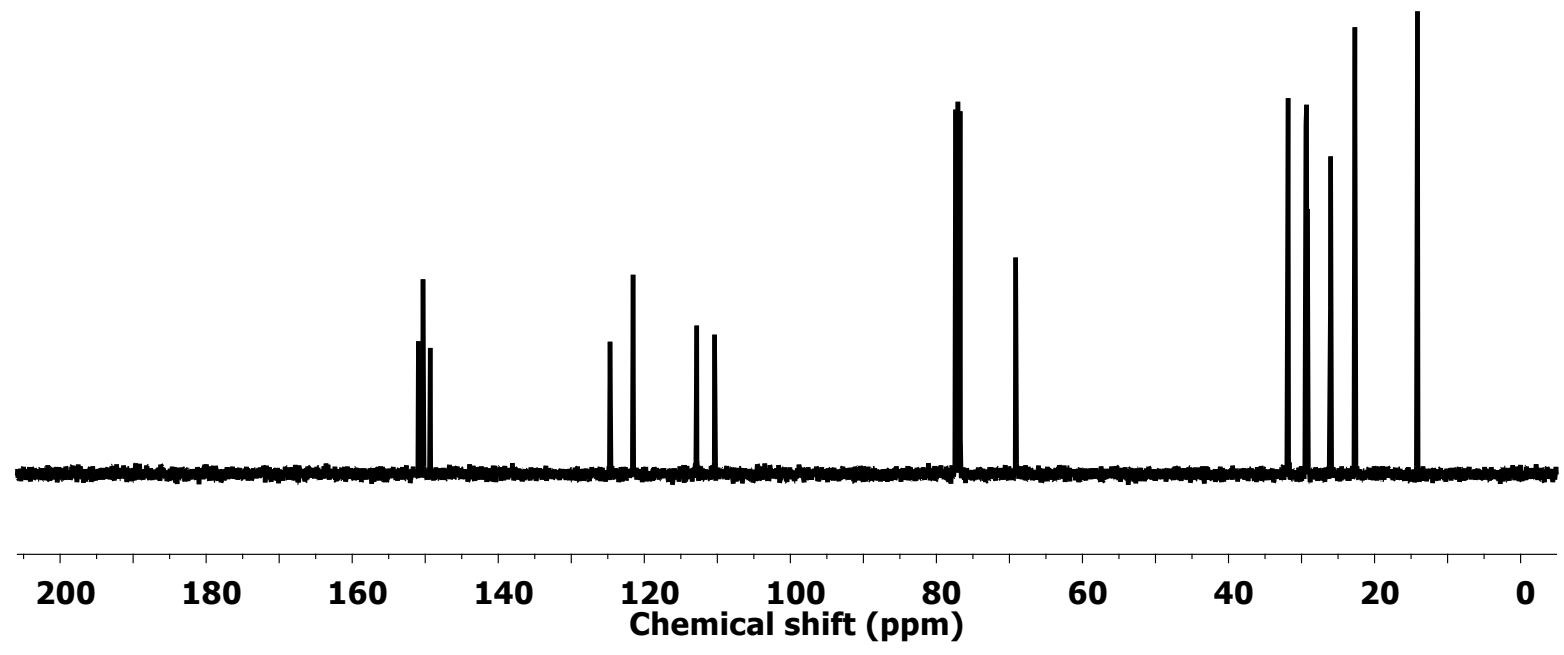

Figure S10: ${ }^{13} \mathrm{C}$ NMR spectrum of $4 \mathrm{a}$ in $\mathrm{CDCl}_{3}$ recorded at $298{ }^{\circ} \mathrm{K}$. 


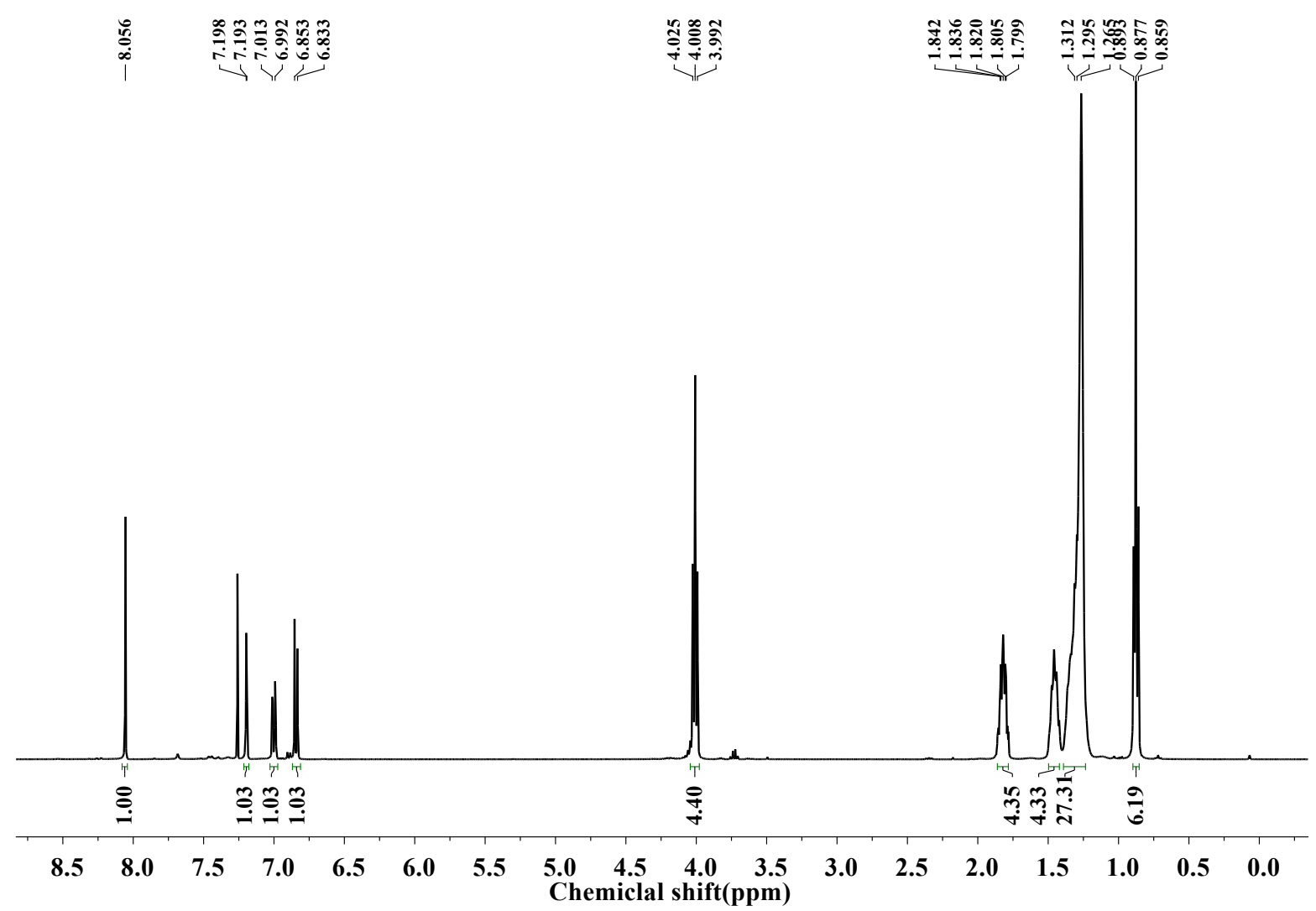

Figure S11: ${ }^{1} \mathrm{H}$ NMR spectrum of $4 \mathrm{~b}$ in $\mathrm{CDCl}_{3}$ recorded at $298{ }^{\circ} \mathrm{K}$.

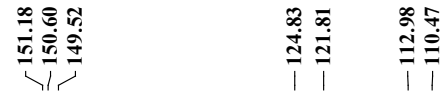

:

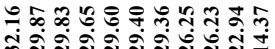

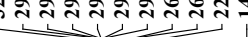

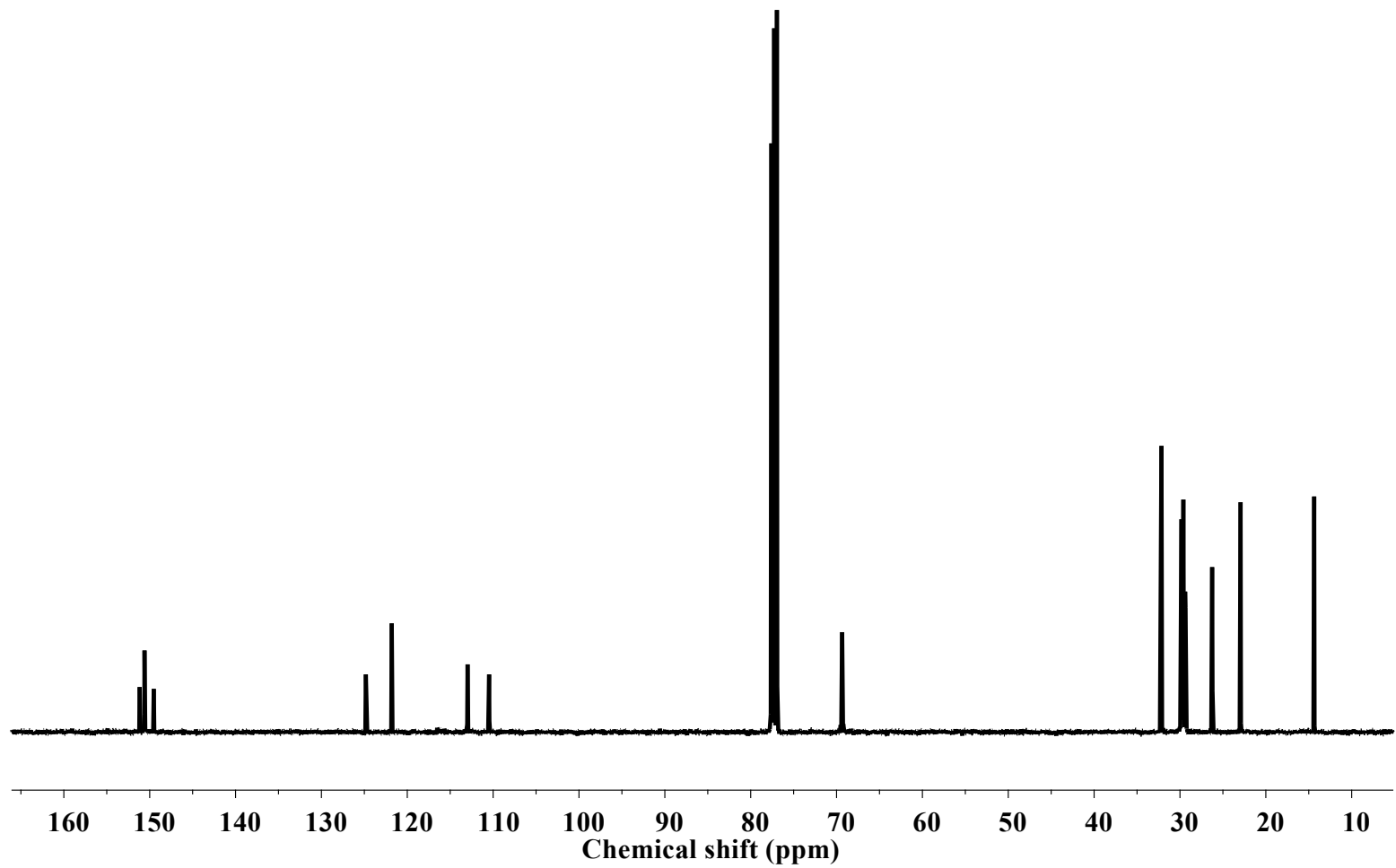

Figure $\mathrm{S} 12:{ }^{13} \mathrm{C}$ NMR spectrum of $4 \mathrm{~b}$ in $\mathrm{CDCl}_{3}$ recorded at $298{ }^{\circ} \mathrm{K}$. 


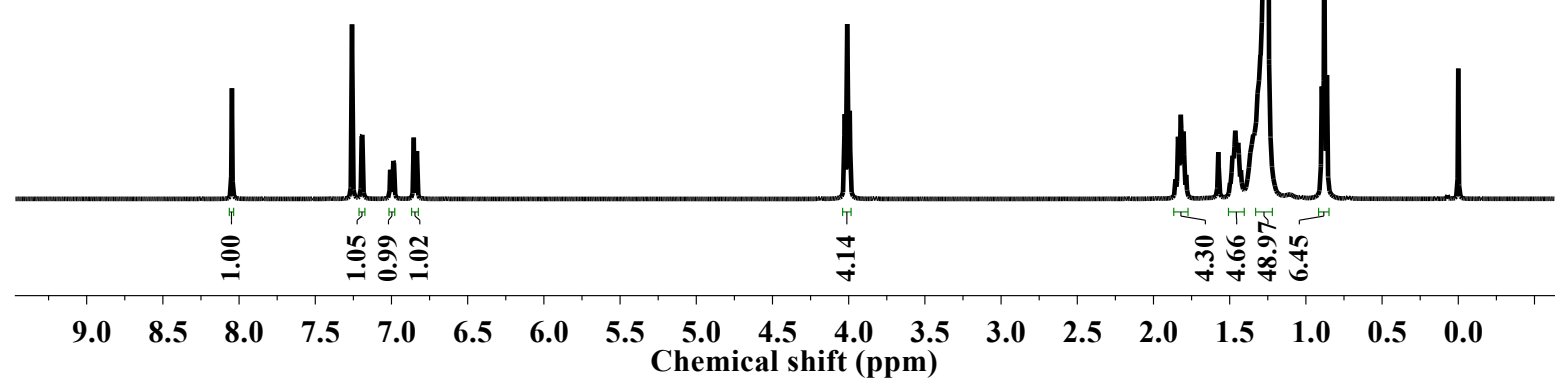

Figure S13: ${ }^{1} \mathrm{H}$ NMR spectrum of $4 \mathrm{c}$ in $\mathrm{CDCl}_{3}$ recorded at $298{ }^{\circ} \mathrm{K}$.

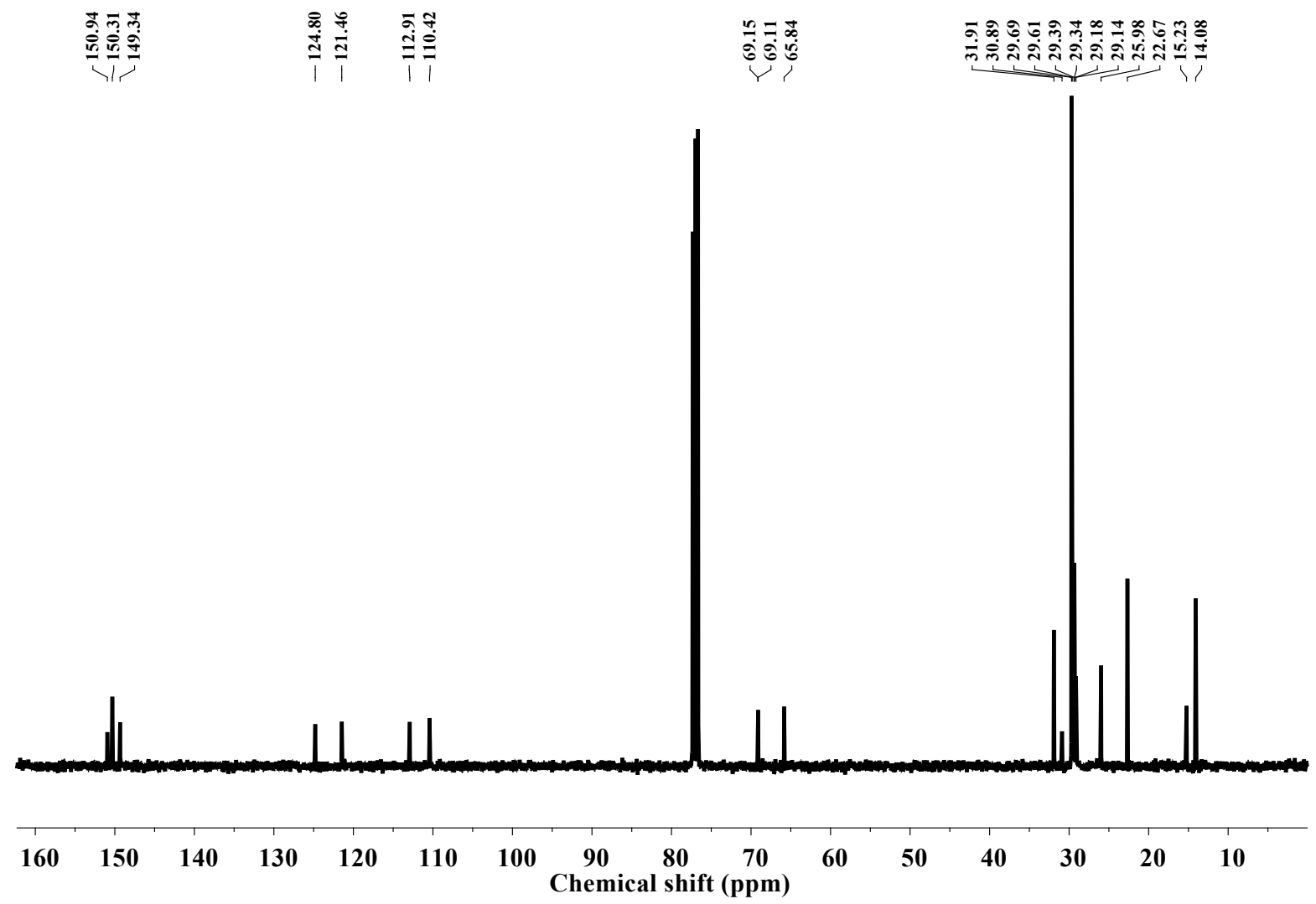

Figure $\mathrm{S} 14:{ }^{13} \mathrm{C}$ NMR spectrum of $4 \mathrm{c}$ in $\mathrm{CDCl}_{3}$ recorded at $298{ }^{\circ} \mathrm{K}$. 


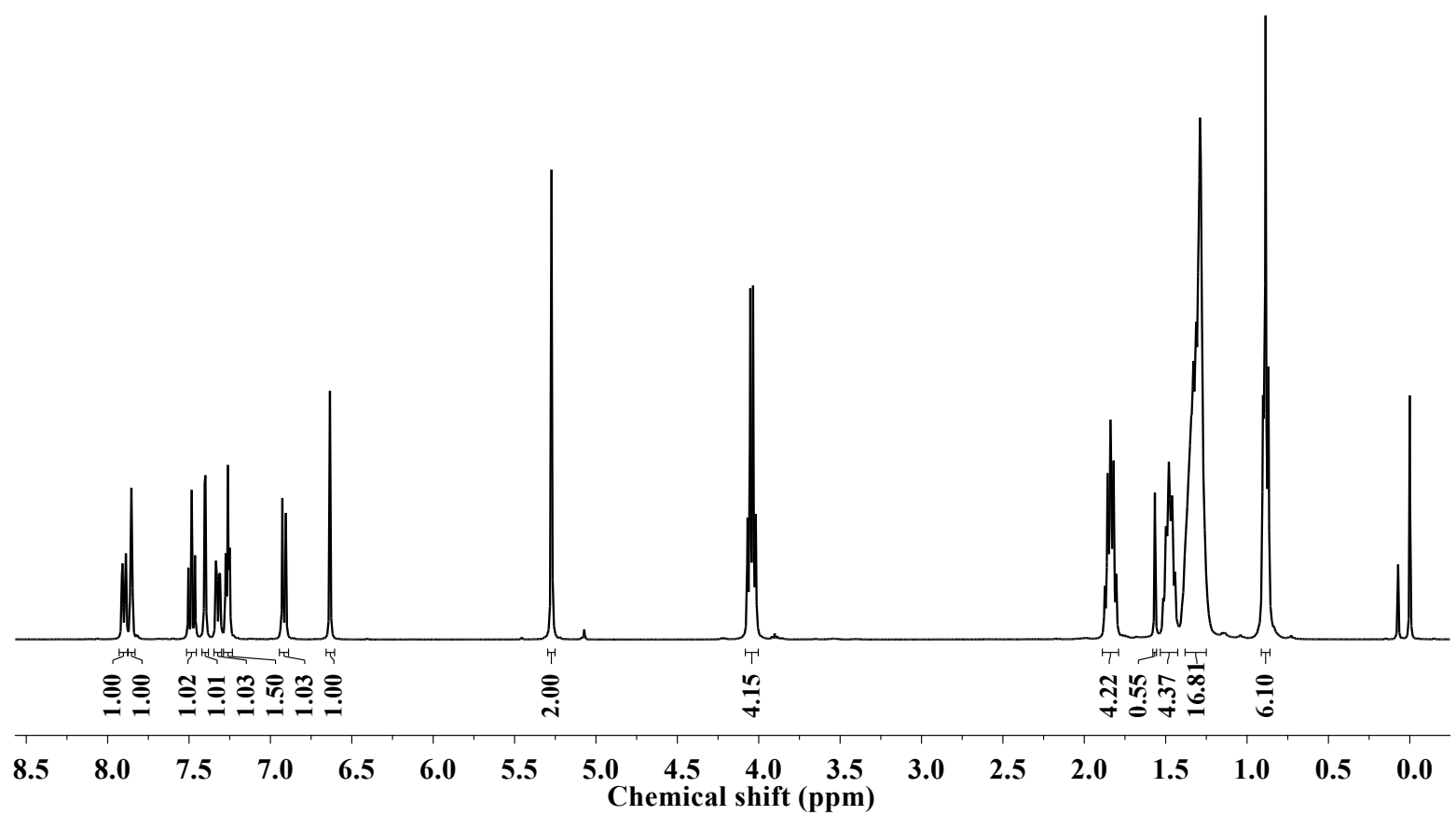

Figure S15: ${ }^{1} \mathrm{H}$ NMR spectrum of $\mathrm{Ga}$ in $\mathrm{CDCl}_{3}$ recorded at $298{ }^{\circ} \mathrm{K}$.

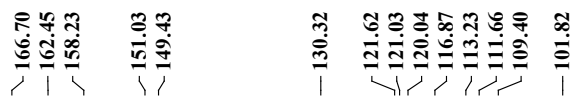

Figure $\mathrm{S} 16:{ }^{13} \mathrm{C} \mathrm{NMR}$ spectrum of $\mathrm{Ga}$ in $\mathrm{CDCl}_{3}$ recorded at $298{ }^{\circ} \mathrm{K}$. 


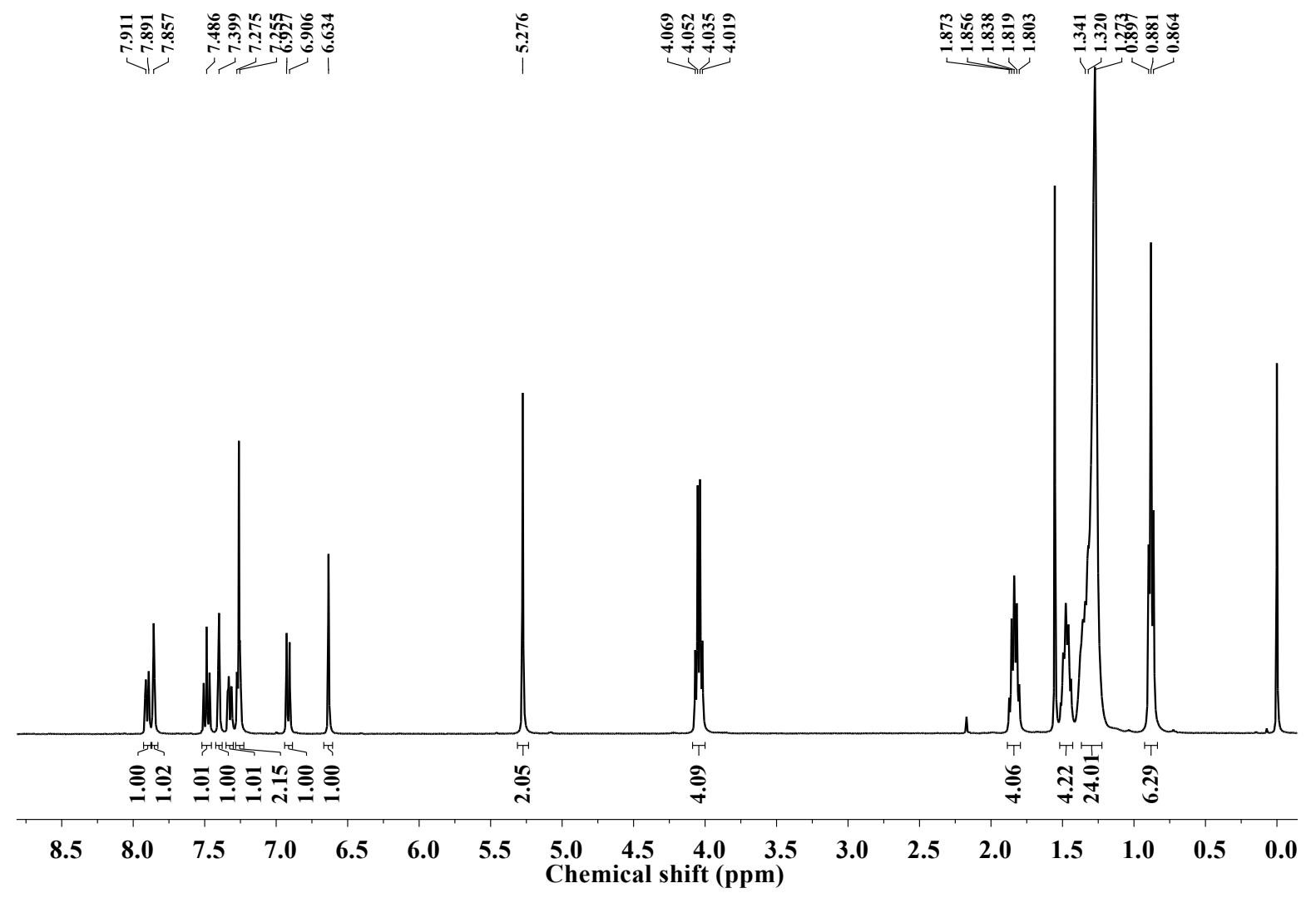

Figure S17 : ${ }^{1} \mathrm{H}$ NMR spectrum of $\mathrm{Gb}$ in $\mathrm{CDCl}_{3}$ recorded at $298{ }^{\circ} \mathrm{K}$.

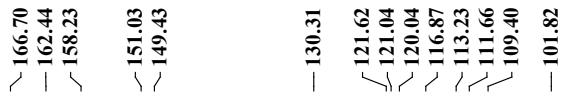

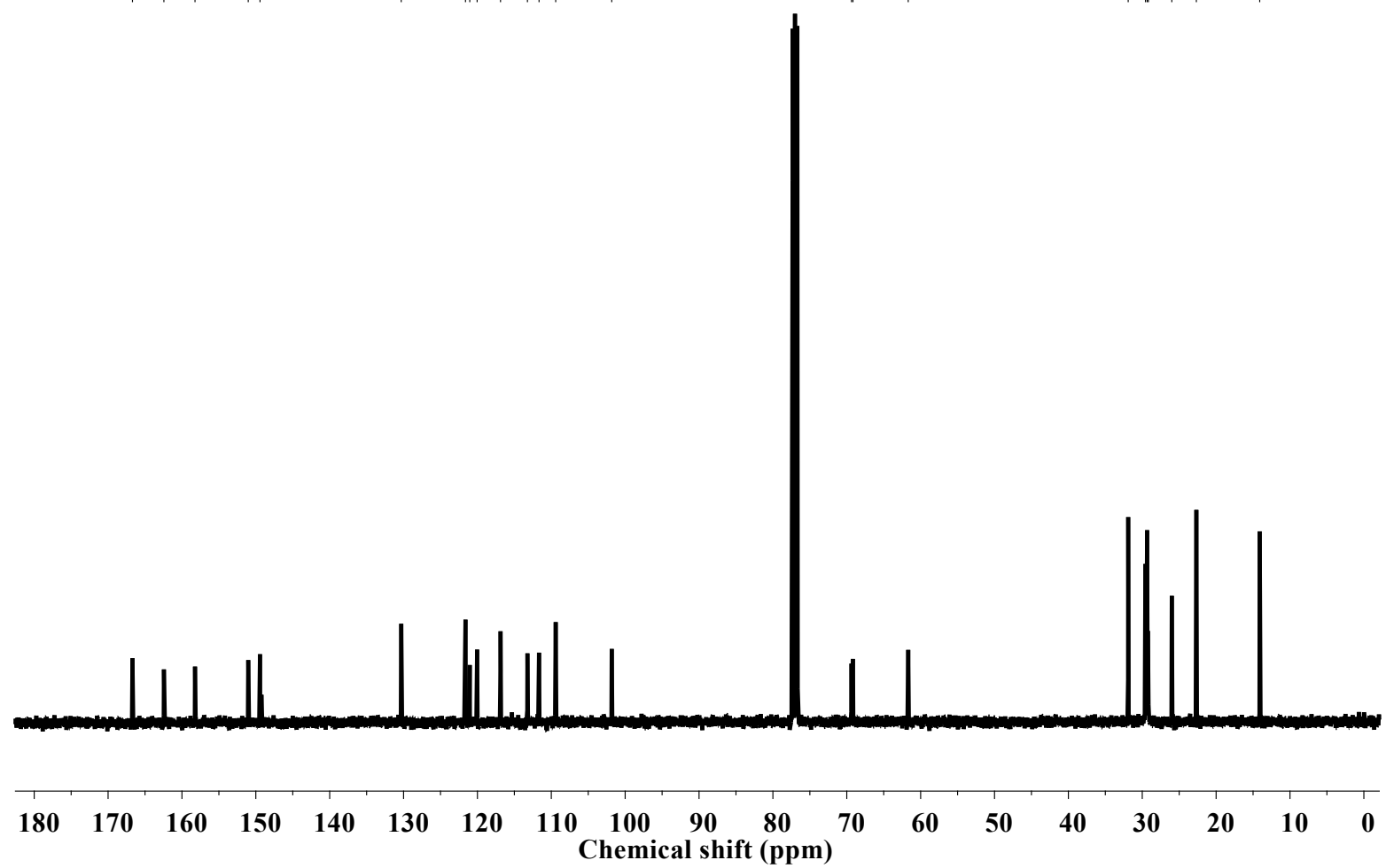

Figure $\mathrm{S} 18:{ }^{13} \mathrm{C}$ NMR spectrum of $\mathrm{Gb}$ in $\mathrm{CDCl}_{3}$ recorded at $298{ }^{\circ} \mathrm{K}$. 


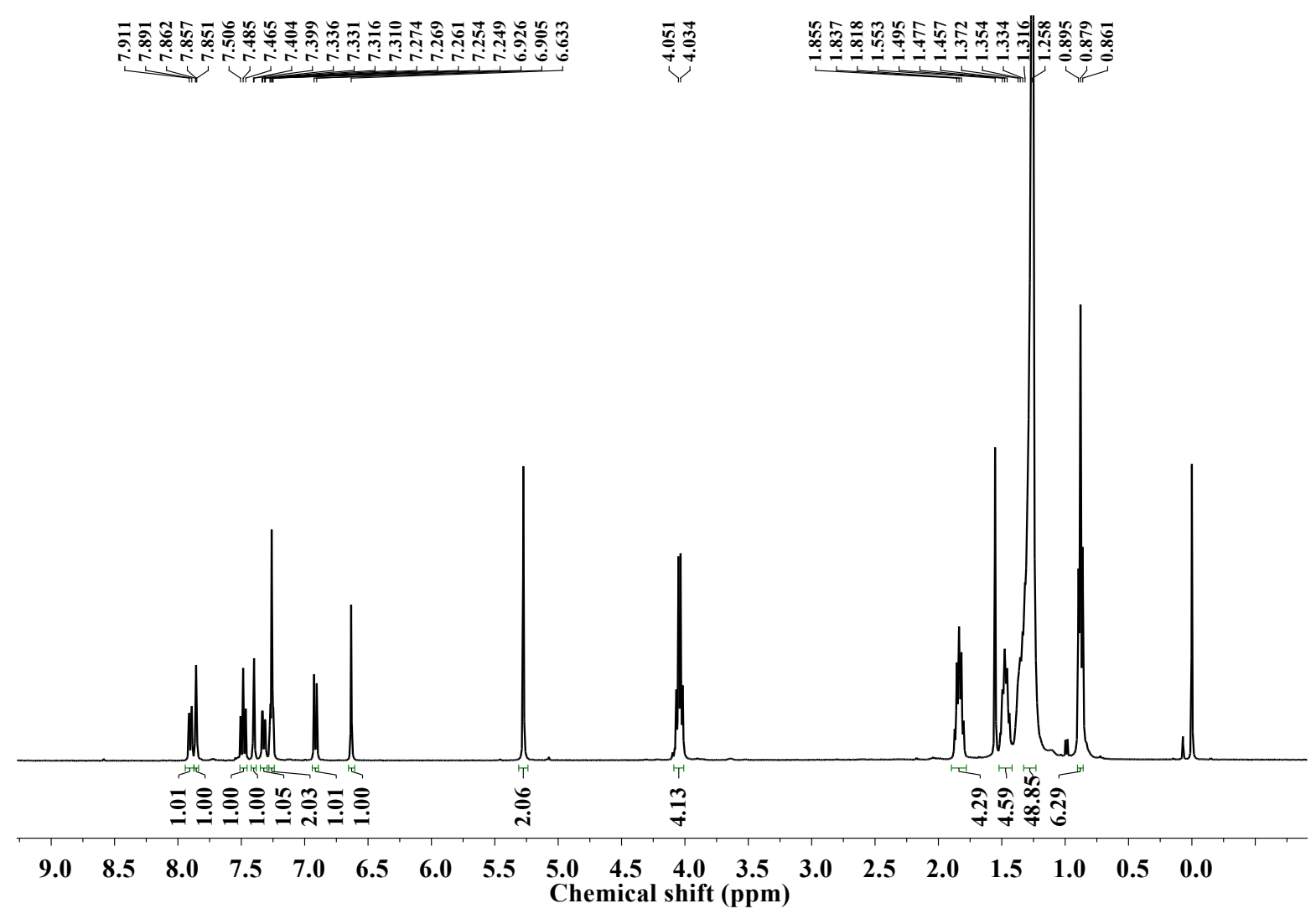

Figure S19 : ${ }^{1} \mathrm{H}$ NMR spectrum of $\mathrm{Gc}$ in $\mathrm{CDCl}_{3}$ recorded at $298{ }^{\circ} \mathrm{K}$.

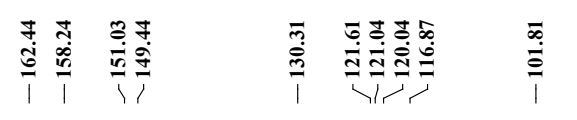

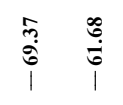

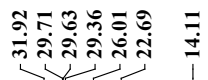

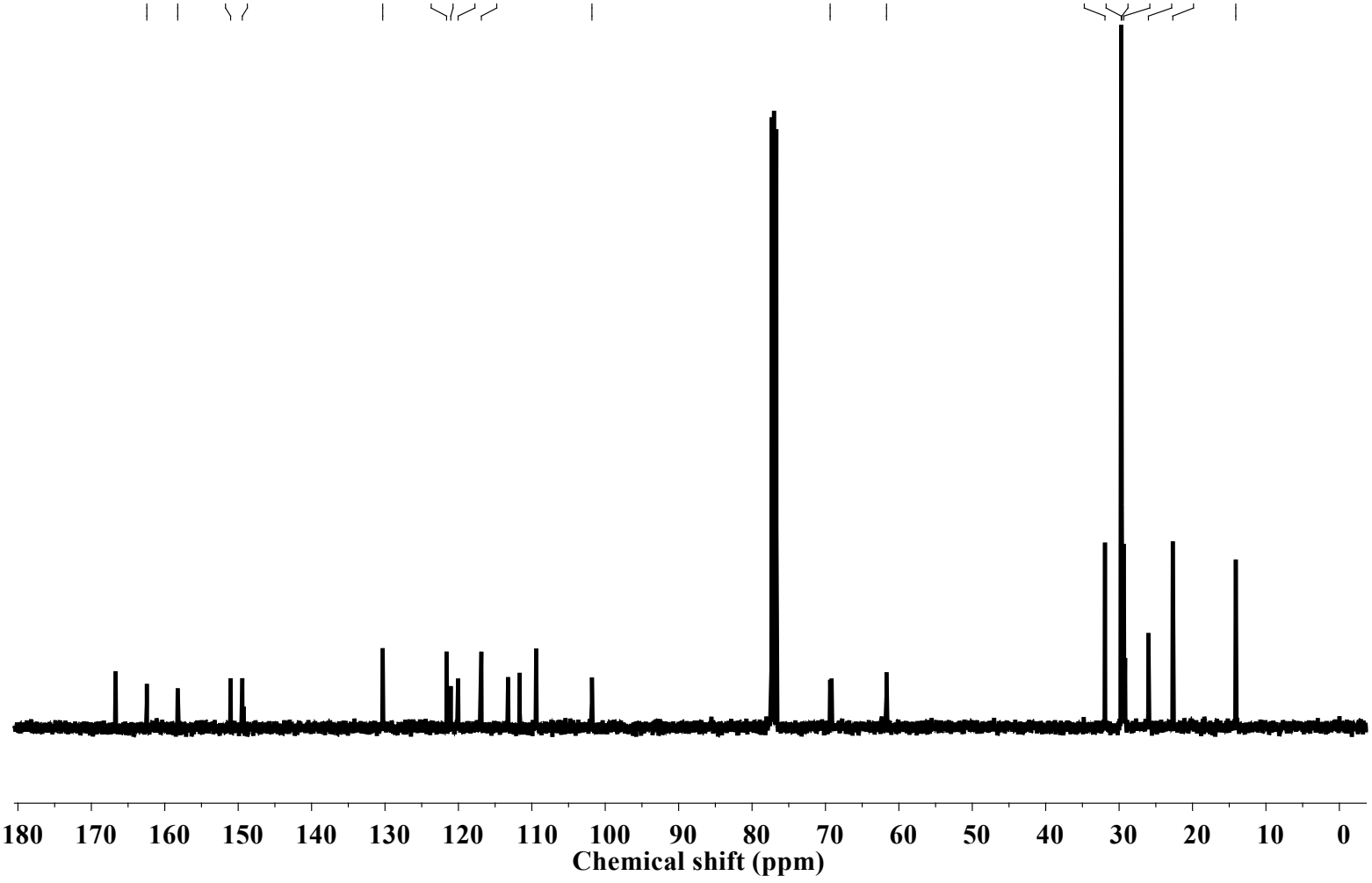

Figure S20: ${ }^{13} \mathrm{C}$ NMR spectrum of $\mathrm{Gc}$ in $\mathrm{CDCl}_{3}$ recorded at $298^{\circ} \mathrm{K}$. 